\title{
Forest fires in Volga federal district of the Russian Federation (2000-2020 years)
}

\author{
Alsu Fazylova ${ }^{1, *}$, Elina Nasyrova $^{1}$, Liana Faritova ${ }^{1}$, and Alexey Elizaryev ${ }^{1}$ \\ ${ }^{1}$ Ufa State Aviation Technical University, Department of Fire Safety, 12, K. Marx Street, Ufa, \\ 450000 , The Republic of Bashkortostan, Russia
}

\begin{abstract}
Using statistical data, the dynamics of forest fires in the Volga federal district of the Russian Federation from 2000 to 2020 years is analyzed. The number and area of forest fires were considered as the initial data. At the same time, the total area of forest fire and of burned forests were taken into account separately. It was found that during the period under review, the minimum number of fires was recorded in 2000, and the maximum in 2018. Out of 14 subjects included in the Volga federal district, forest fires in the Republic of Bashkortostan were studied in detail. The dependence of the number of fires by season is established. Using correlation analysis of the statistical data for 2000-2020, the fact of strong dependence between the number of fires in the Volga federal district and forest area covered by fire was established.
\end{abstract}

\section{Introduction}

Forest fires are one of the main problems that threaten forest ecosystems around the world and have serious consequences. When studying forest fires, two aspects arise: what data to use and in what territorial boundaries to analyze this data. In general, forest fires are investigated using statistical, satellite and meteorological data [1-5]. Statistics can be: official data of public bodies (ministries and departments); press releases and industry magazines. All this available sources of data have their quality [6].

For example, authors [7] for estimating the extent areas affected by forest fires had used Sentinel 2 images $(10$ and $20 \mathrm{~m}$ ) for fires occurred in October 2017 in Spain and Portugal. Xiaorui Tian et. all [8] in their work combined satellite data on the occurrence of hotspots and statistical data for analyzing the distribution characteristics of wildfires for 2008-2012. Ana Teodoro and Ana Amaral in their work [9] analyzed data from Landsat 8 OLI and Sentinel 2A MSI (prefire and postfire data). I. Tošić et. all examined potential links between meteorological variables and forest fires in Serbia. For this purpose, data on daily temperature, precipitation, relative humidity and wind speed were used from 15 weather stations across of Serbia [5].

With regard to the territorial component, researchers in their works mainly adhere for administrative division. For example, Ismael Vallejo-Villalta et. all considered the area of the municipal territory of Algodonales in Spain [3]. The entire territory of Italy with the use

\footnotetext{
* Corresponding author: alsy-fazylova2013@yandex.ru
} 
of time series analysis was studied by Margherita Carlucci et. all [4]. Spatial and temporal distribution of forest fires in Nepal is analyzed in work [10].

As is known, for occurring fire three conditions must be met simultaneously: the presence of fuel, an oxidizer and ignition source. Regarding forest fires, the forest itself is combustible, and the oxidizer is oxygen contained in the atmospheric air. When conducting a correlation analysis, first of all, the probability of a forest fire from meteorological parameters is analyzed. They affect on forest combustibility and the appearance of ignition source.

For example, in the article [11] authors discusses the differences of meteorological factors influence on forest fires occurrence in two climatically contrasted forestries of the Republic of Buryatia. In the other work [12] five meteorological fire risk indices are calculated for 13 German states between 1993 and 2010. Tamiozzo Pereira Torres et. all analyzed the efficiency of Fire Weather Index (FWI), Logarithmic of Telicyn Index, Nesterov Index, cumulative indexes of precipitation - evaporation (P-EVAP) and evaporation / precipitation (EVAP/P), Monte Alegre Index (FMA) and Monte Alegre Changed Index (FMA+) in the prediction of forest fires for the city of Viçosa (MG) [13]. Other authors in the work [14] had crossed correlations between total areas burned and mean FWI of the current season in Greece, Spain and Finland.

The purpose of this article is to estimate the temporal and spatial distribution of forest fires in Volga federal district (Russia) for last 20 years. Also in work is providing a correlation analysis between number of fires and the forest area.

\section{Materials and methods}

The Russian Federation is the world leader in forest area - 1184.1 million hectares, or $20 \%$ of the total forest area of the world. One of the main features of the forests geography is their uneven territorial distribution. For 2019, the forest cover of the Russian Federation federal districts is shown in Figure 1.

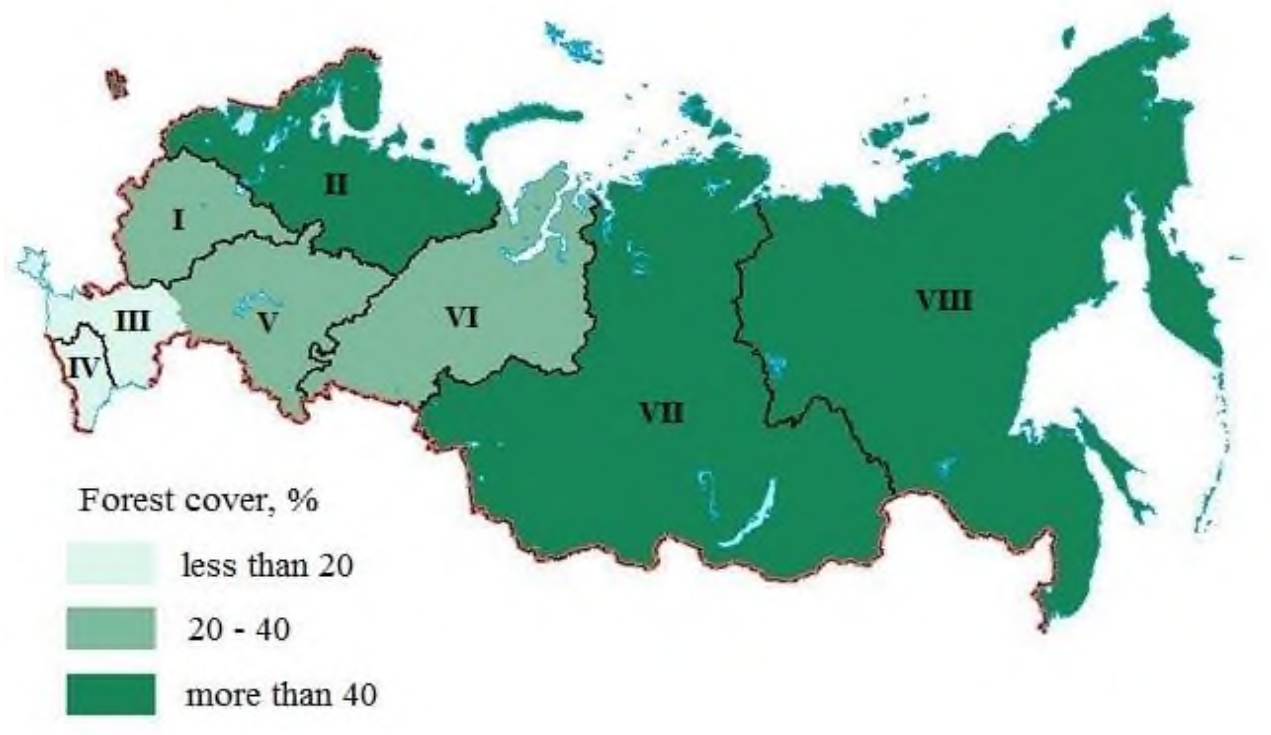

Fig. 1. Forest cover of the territory of the Russian Federation in the context of federal districts: $I-$ Central; II-Northwestern; III - Southern; IV-North Caucasian; V-Volga; VI-Ural; VIISiberian; VIII - Far Eastern 
The presence of large forest areas causes the annual occurrence of fires from 10 to 15 thousand per year [15]. The Russian Federation includes 8 federal districts, which in turn are divided into regions, and regions into areas. In studying of forest fires it is also important to divide the areas into forestry. However, they are not tied to one area, but rather combine several. For example, the spatial distribution of fires on the territory of Russia from 1947 to 1996 was studied in [16], focusing on administrative divisions and forestry.

In this work, we consider one of the federal districts of Russia - the Volga federal district.

The Volga Federal District is a federal district of the Russian Federation, formed by the Decree of the President of the Russian Federation on May 13, 2000. The district consists of 14 regions: 6 republics (Mordovia, Chuvash, Tatarstan, Bashkortostan, Mari-El and Udmurt), 1 territory (Perm) and 7 districts (Saratov, Penza, Ulyanovsk, Samara, Orenburg, Nizhny Novgorod and Kirov).

Volga Federal District has various climates. The natural areas of the district range from taiga to semi-deserts. In the direction from north to south, zonal types of ecosystems replace each other: dark coniferous middle taiga forests, dark coniferous southern taiga forests with oak elements, coniferous broad-leaved forests, meadow steppes, real steppes, desert steppes. In addition, intrazonal swamp ecosystems are widely represented in the district, as well as azonal ecosystems: pine forests, floodplain, coastal and aquatic communities, and mountain landscapes. The area of coniferous plantations is $42.8 \%$ of the total area of the forest fund, hard-leaved-4.9\%, soft-leaved-43.3\%.

On the territory of Volga Federal District since 2009, there has been a decrease in forest cover and a stable percentage in 2011-2016. In subsequent years, there is a slight increase to $36.5 \%$. The forest cover of the Volga Federal District causes the annual occurrence of forest fires in each of its regions.

\section{Results and discussion}

In the research data on forest fires from the remote monitoring information system of the Federal Forestry Agency were used. Considering the statistics for the period 2000-2020 among the federal districts, it can be noted that the Volga Federal District in 2000 ranks 7 th in terms of the number of fires, in 2001 the number of forest fires increases by $39 \%$. It is also worth emphasizing that the ratio of 2000 to 2020 revealed an increase in fires by 19.1 times. In comparison with other federal districts, Volga Federal District in 2007 has the minimum number of forest fires. 


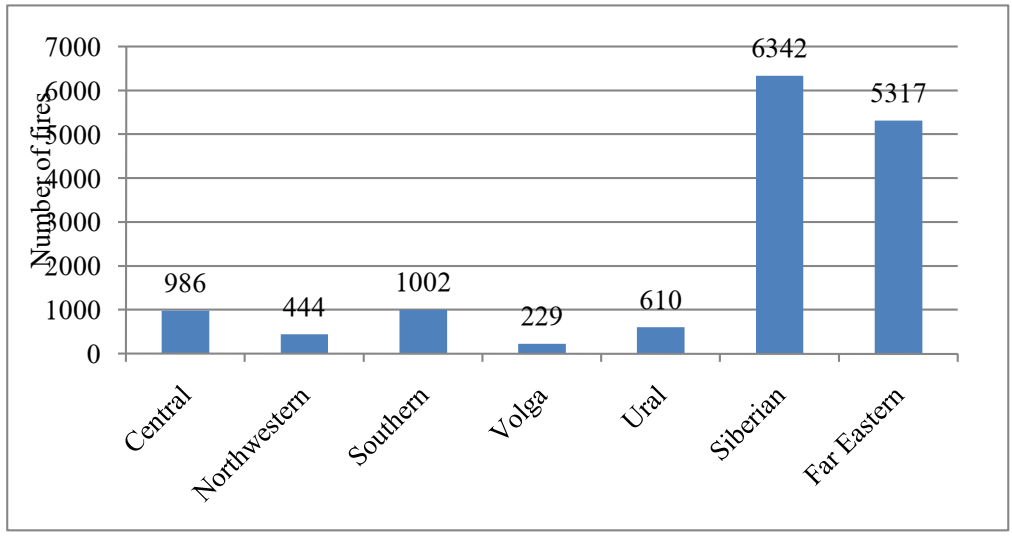

Fig. 2. Number of fires in federal districts in 2007

As can be seen from Figure 2, the number of forest fires in the Volga Federal District in 2007 is $3.6 \%$ of the Siberian Federal District, which, in turn, has the maximum number of fires, and $4.3 \%$ of the Far Eastern Federal District - the second largest number of cases after the Siberian. A detailed analysis of forest fires in the Siberian Federal District is carried out in [17].

Considering forest fires for 20 years in the Volga Federal District, we can distinguish 2000 and 2018, which have, respectively, the minimum and maximum number of fires. Let's consider in detail the year 2018 for the regions of the Volga Federal District.

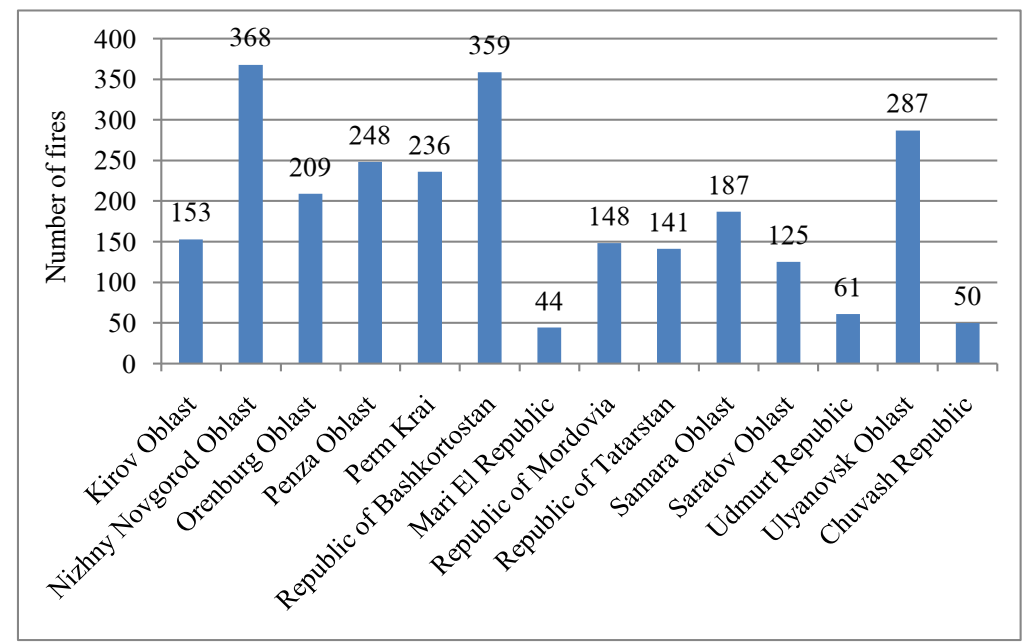

Fig. 3. Dynamics of forest fires in the regions of the Volga Federal District in 2018 
The Volga Federal District regions have different degrees of forest cover (from 4 to $71 \%$ ). The largest number of forest fires recorded in 2018 in the Nizhny Novgorod region is 368 cases with an area of 5253 ha, also with a slight lag in the Republic of Bashkortostan359 cases with an area of 8795 ha, and the smallest-the Republic of Mari-El (44 cases, 658 ha). For example, in the Nizhny Novgorod region, the largest forest fire was with an area of 623 hectares in the Kstovsky interdistrict forestry. In the Republic of Mari-El (Mari-Turek forestry), this value is less - 153 hectares. The largest fire in the Republic of Bashkortostan occurred in the Zilar forestry, where the total area of fires was 995 hectares. From the fire card - the fire started on 4.05.2018 and was completely eliminated only on 12.05.2018.

In the Republic of Bashkortostan for the period from 2000 to 2020, the maximum number of fires was recorded in May 2018 - 162 cases, with an area of 7539 hectares, with $50 \%$ in the month's middle. On average, this is $44.9 \%$ of the total number of fires. In April, a significant part of the fires occurred in the month's middle. Fires at the beginning of the fire-dangerous period (April-May) occur due to agricultural fires and the cultivation of bonfires by the population. For the spring period, low-level fires of medium intensity are typical, when last year's dead and dried grass, fallen branches and leaves are burning.

The summer period was not distinguished by large fires; the average area covered by fire for a month was 239.3 hectares. The share of forest fires does not exceed $20 \%$ of the total number.

In the autumn period, grass-roots fires are also characteristic, when frosts are observed at night, and during the day - positive air temperatures, which leads for rapid drying of herbaceous vegetation. So, in September, 42 cases were recorded, with an area of 527 hectares, and in October - 37 cases, with an area of 433 hectares.

The paper presents a correlation analysis of the number of forest fires; the area covered by fire; forest cover and forest area in the Volga Federal District regions in 2018.

Table 1. Correlation analysis in the Volga Federal District regions in 2018

\begin{tabular}{|c|c|c|c|c|}
\hline & $\begin{array}{c}\text { Number of } \\
\text { forest fires }\end{array}$ & $\begin{array}{c}\text { Forest cover } \\
\text { (percentage) }\end{array}$ & $\begin{array}{c}\text { Forest land } \\
\text { area, (thousand } \\
\text { hectares) }\end{array}$ & $\begin{array}{c}\text { Forest area } \\
\text { covered by } \\
\text { fire (ha) }\end{array}$ \\
\hline Number of forest fires & 1 & & & \\
\hline Forest cover (percentage) & 0.017 & 1 & & \\
\hline $\begin{array}{c}\text { Forest land area, } \\
\text { (thousand hectares) }\end{array}$ & 0.328 & 0.78 & 1 & 1 \\
\hline $\begin{array}{c}\text { Forest area covered by fire } \\
\text { (ha) }\end{array}$ & 0.876 & -0.15 & 0.14 & 1 \\
\hline
\end{tabular}

A high correlation between the number of fires and the area of the forest covered by the fire was revealed. There is a moderate correlation between the number of fires and the forest area. In this regard, for establishing the relationship between number of forest fires and their area, a correlation analysis was carried out for Volga Federal District regions for 2007-2017 (Table 2). 
Table 2. Results of correlation analysis of fires in the Volga Federal District for 2007-2017

\begin{tabular}{|c|c|c|}
\hline Year & $\begin{array}{c}\text { Correlation coefficient } \\
\text { between number of fires and } \\
\text { its area }\end{array}$ & $\begin{array}{c}\text { The closeness of the } \\
\text { connection }\end{array}$ \\
\hline 2007 & 0.93 & Very high \\
\hline 2008 & 0.91 & Very high \\
\hline 2009 & 0.88 & High \\
\hline 2010 & 0.49 & Moderate \\
\hline 2011 & 0.87 & High \\
\hline 2012 & 0.94 & Very high \\
\hline 2013 & 0.61 & Notable \\
\hline 2014 & 0.84 & High \\
\hline 2015 & 0.80 & High \\
\hline 2016 & 0.80 & High \\
\hline 2017 & 0.92 & Very high \\
\hline
\end{tabular}

From the Table 2 it can be seen that mainly for the analyzed period there is a correlation between the area of fires and their number, the closeness of which is expressed on the Cheddock scale. In the study period, only in 2010 the correlation coefficient is low, and, accordingly, the closeness of the connection. In 2010, an abnormally long presence of an anticyclone was observed in the European part of Russia from June 21 to August 19. For two months, the central part of Russia remained without precipitation and recorded abnormally high temperatures. These climatic features were reflected on the results of correlation analysis.

\section{Conclusion}

The paper considers the main approaches used in the analysis of forest fires. Using statistical data, the dynamics of forest fires in the Volga federal district of the Russian Federation from 2000 to 2020 years is analyzed. The number and area of forest fires were considered as the initial data. At the same time, the total area of forest fire and the area of burned forests were taken into account separately. It was found that during the period under review, the minimum number of fires was recorded in 2000, and the maximum in 2018. Out of 14 subjects included in the Volga federal district, forest fires in the Republic of Bashkortostan were studied in detail. The dependence of the number of fires by season is established. Using correlation analysis of the statistical data for 2000-2020, the fact of strong dependence between the number of fires in the Volga federal district and forest area covered by fire was established. In the study period, only in 2010 the correlation coefficient was low- 0.49 , respectively, and the closeness of the connection was moderate. The next stages of this work is identifying the relationship between the number of fires and forest area of forestries that are part of the Volga federal district. At the same time, it is interesting to analyze the relationship between the number of forest fires and the population in regions.

\section{References}

1. A. Jaafari, D. Mafi-Gholami, B. Thai Pham, D. Tien Bui. Remote Sensing, 11(6), 618 (2019)

2. A. C. Meira Castro, A. Nunes, A. Sousa, L. Lourenço, Geosciences, 10(2), 53 (2020)

3. I. Vallejo-Villalta, E. Rodríguez-Navas, J. Márquez-Pérez, Environments, 6(3), 30 (2019). 
4. M. Carlucci, I. Zambon, A. Colantoni, L. Salvati, Sustainability, 11(5), 1305 (2019)

5. I. Tošić, D. Mladjan, M.B. Gavrilov, S. Živanović, M.G. Radaković, S. Putniković, P. Petrović, I. K. Mistridželović, S. B. Marković, Open Geosciences, 11(1), 414-425 (2019)

6. A. I. Pyzhev, R. V. Gordeev, E. A. Vaganov, Sustainability, 13(1), 86 (2021)

7. R. Llorens, J. A. Sobrino, C. Fernández, J. M. Fernández-Alonso, J. A. Vega. International J. Appl. Earth Observation and Geoinformation, 95 (2021)

8. X. Tian, F. Zhao, L. Shu, M. Wang, Forest Ecology and Management, 310, 460-467 (2013)

9. A. Teodoro, A. Amaral, Environments, 6(3), 36 (2019)

10. A. Parajuli, D. B. Chand, B. Rayamajhi, R. Khanal, S. Baral, Y. Malla, S. Poudel, Conference: XIV WORLD FORESTRY CONGRESS, FAOAt: Durban, South Africa (2015)

11. N. Badmaev, A. Bazarov, Agricultural and Forest Meteorology, 297, 108245 (2021)

12. A. Holsten, A. R. Dominic, L. Costa, J. P. Kropp, Forest Ecology and Management, 287, 123-131 (2013)

13. F. T. P. Torres, G. S. Lima, S. V. Martins, S. R. Valverde, Revista árvore, 41(2), e410209 (2017)

14. A. Venäläinen, N. Korhonen, O. Hyvärinen, N. Koutsias, F. Xystrakis, I. R.Urbieta, J. M. Moreno, Nat. Hazards Earth Syst. Sci., 14(6), 1477-1490 (2014)

15. A. Ostapenko, IOP Conf. Ser.: Earth Environ. Sci. 392012074 (2019)

16. G. N. Korovin, In: J. G. Goldammer, V. V. Furyaev (eds) Fire in Ecosystems of Boreal Eurasia. Forestry Sciences. 48, 112-128, Springer, Dordrecht. (1996)

17. E. N. Valendik, In: Goldammer J.G., Furyaev V.V. (eds) Fire in Ecosystems of Boreal Eurasia. Forestry Sciences, 48, 129-138, Springer, Dordrecht (1996) 